\title{
Final Year Student's Perception before Engaging Engineering Technology Program in UTeM
}

\author{
${ }^{1}$ Mohamad Haniff Harun, ${ }^{1}$ Umar Al-Amani Azlan, ${ }^{1}$ Nor Hamizah Miswan, ${ }^{1}$ Khairum \\ Hamzah, ${ }^{1}$ Ahmad Zubir Jamil, ${ }^{1}$ Rohana Abdullah and ${ }^{1}$ Mohd Rahimi Yusoff \\ ${ }^{l}$ Faculty of Engineering Technology, Universiti Teknikal Malaysia Melaka, Hang Tuah Jaya, 76100, Durian \\ Tunggal, Melaka, Malaysia \\ Ihaniff@utem.edu.my
}

\begin{abstract}
In line with industrial development which is growing rapidly in Malaysia, the country is in great needs of competent technical workforce able to apply the latest concept of technology, improve equipment and system utilization, optimizing operation and maintenance of equipment. Therefore, an engineering technology program will be introduced in Malaysia education system at higher level. In determining the perception of Engineering Technology program in Universiti Teknikal Malaysia Melaka (UTeM), a market survey has been conducted to gather the perception of the final year students about Engineering Technology. Total numbers of 123 students from Cohort 1 with two different departments, electrical and manufacturing were used as a sample space. The scope of the market survey covered regarding their perspective and understanding of Engineering Technology before enrolling engineering technology program from their perspective courses. The findings show that there is a difference perception in overall especially regarding their understanding of terms Engineering Technology Programs.
\end{abstract}

Index Terms- Engineering Technology, Manufacturing and Electrical

\section{INTRODUCTION}

Engineering technology and engineering have become the essential goal for many countries where there are great needs of competent technical workforce. There is an interface between engineering technology and engineering people in workplace whereby technologists focus more on application and implementation while engineers focus more on research and development [1]. Preparation to provide technical workforce in engineering technology starts from the educational stage especially at higher learning institutions. Many higher learning institutions have developed engineering technology program curriculum. Several studies regarding the technology program were done and reported [1-2]. Engineering technology program that is able to provide competent and high-skilled workforce has become crucial and more demanding from industrial. Not only for undergraduate program, there is a study report that suggests master program in engineering management specifically targeted at graduates of an engineering technology program [3].

A part of engineering technology, the electrical engineering technology program has been developed for the purpose of preparing workforce who is able to operate facilities in the field of power engineering industry especially in electric power generation industry, renewable power generation, transmission, distribution of power, the utilities, maintenance, electrical installations and electrical power system design. The approach of teaching methods and current curricular for electrical was studied to provide educators about the unclear topics and concepts to the future of electrical technologist [4-6]

For Manufacturing Engineering Technology focuses primarily on analyzing, applying, implementing, and improving existing technologies and is aimed at preparing graduates for the practice of engineering closest to the product improvement, manufacturing, and engineering operational functions. The field of Manufacturing Engineering Technology includes: mechanical design, manufacturing processes, energy utilization, building air conditioning and the economics of these activities. Lectures emphasize applied engineering and are supplemented by extensive laboratory experience. It can be seen that the curricula contents are similar with the traditional 
engineering courses. However the differences are on the mode of deliveries and the breadth and depth of the subjects offered within the specific curricular.

\section{THE PROGRAM SURVEY APPROACH}

The Malaysian Government in Ninth Malaysia Plan (9MP) 2006-2010 and Tenth Malaysia Plan (10MP) 2011- 2015 has emphasized human capital development as the focus in the face of global competition [7]. According to the study for the Third Malaysia Outline Perspective Plan (OPP3) 2001-2010, generally the number of technical workforces needed by the country between 2000 and 2010 amounted to 468,983 engineers and assistant engineers in various fields of engineering including electrical and electronic engineering in the country. Electrical and electronic field requires almost 46,000 engineers and 136,000 assistant engineers [8]. In line with industrial development in Malaysia which is growing rapidly, the country essentially is in need of competent technical personnel that have the ability to apply the concept of technology, improve equipment and system utilization, optimum operation and maintenance of equipment, plant systems and structures to align with workforce in developed countries.

Accordingly, a sophisticated system in the industries require highly skilled and competent person to supervise the installation tests, operations, maintenance links and also management. In addition, the industries also require skilled workers, who have strong knowledge that are able to innovate, modify and operate most of the processes and facilities in the field of electrical and mechanical engineering. Moreover, service sector area also requires electrical and mechanical engineering technology graduates in order to serve the electric power generation industry, renewable power generation, transmission, distribution of power, the utilities, maintenance and electrical installations, and electrical power system design for electrical and for mechanical serve more in apply current technologies and principals from machine and product design, production and material and manufacturing processes.

Therefore, professional and skilled workforce that will be produced in the field of Electrical and Mechanical Engineering as in mentioned sectors are in great demand. Although, the engineers currently produced by the local public university (IPTA) in this field are also able to design and analyze, but they are still lack of practical and technical skills to operate, supervise, maintain, modify and innovate the industry related work [6]. Thus, UTeM plays an important role to complement the industry needs by producing engineering technologists who have technical knowledge and great practical skills.

\section{THE MARKET SERVEY}

A market survey was conducted by the Faculty of Engineering Technology (FTK), UTeM in 2014 with a total of 150 questionnaires distributed to final year students from electrical and mechanical departments which involves 5 courses; 1) Industrial Automation and Robotics; 2) Industrial Power; 3) Refrigeration and Air-Conditioning Systems; 4) Maintenance Technology. From 150 questionnaires distributed, 109 forms had been returned comprising $72.67 \%$ of the total forms distributed. The market survey has covered all the final year students from electrical and mechanical department. Based on the forms received, $37.61 \%$ of the respondents are from Industrial Power, $30.28 \%$ from Industrial Automation and Robotics, $17.43 \%$ from Maintenance Technology and the other are from Refrigeration and Air-Conditioning Systems.

The scope of the market survey includes general understanding of the concept of Engineering Technologists in industries, graduate in industry perspective, the focus areas and the perception students' especially final year students of the Engineering Technology Program. Questionnaire generally focused on the respondents' perception before join Engineering Technology program. Examples of the questions are regarding on their online applications, understanding of Engineering 
Technology itself and resources that encourage them to apply for admission to the program of Engineering Technology.

\section{DATA ANALYSIS}

Based on the analyzed data from Figure 1, it shows that $81.65 \%$ of respondents said that the engineering technology is related to computer technology and Information Technology where respondents felt it was more focused on the use of the technology itself while the rest disagreed with the statement. This is because during their studies at the diploma and matriculation are not emphasized deeply about the real situation between the engineer and technologist. Figure 1 shows the percentage of responses based on their knowledge before undergoing Engineering Technology Courses.

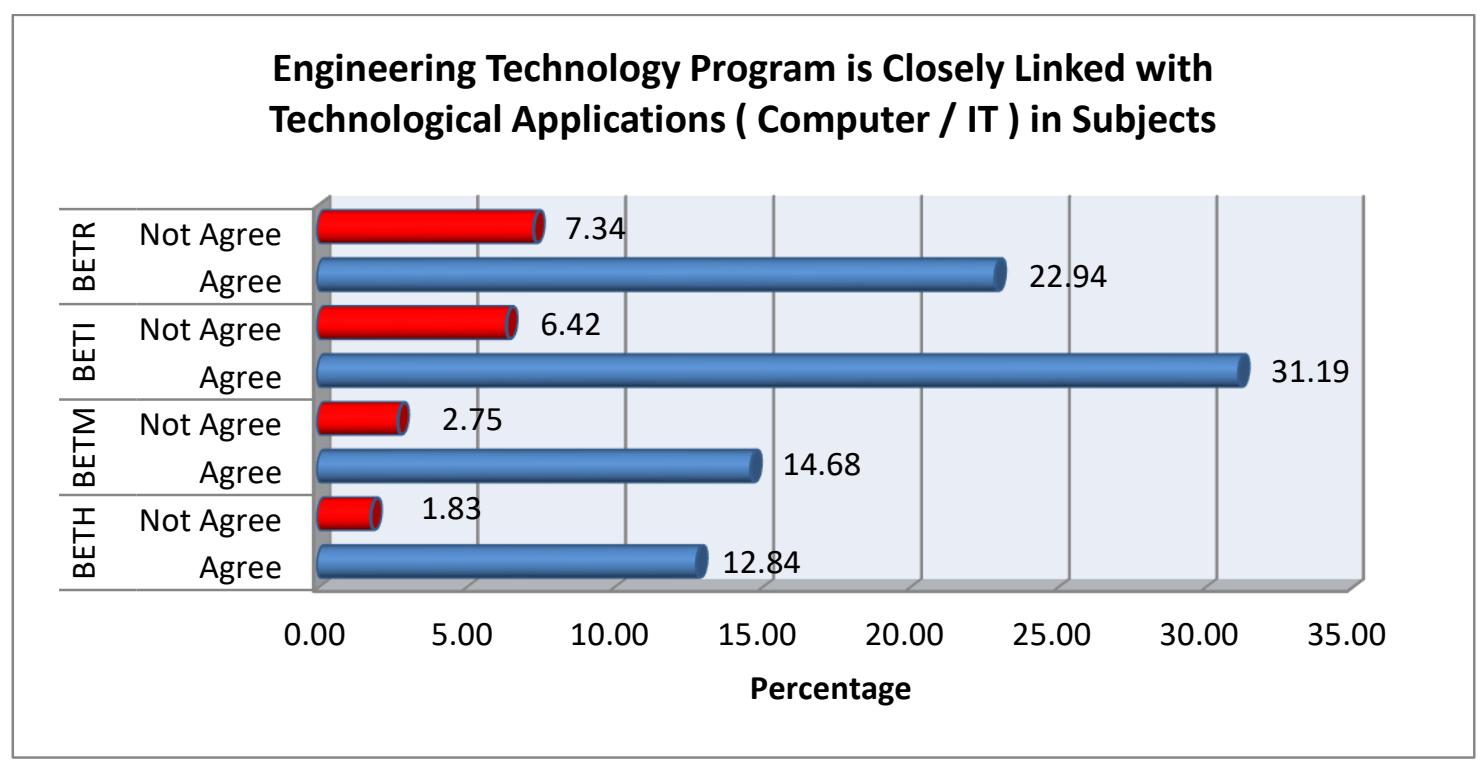

\section{Figure 1 Response students about Engineering Technology program is closely linked with technological applications (computer/IT) in subjects}

Empowerment engineering technology has yet to be carried out predominantly in Malaysia. In connection with the submission process or the whistle blower to students of engineering technology should be given priority so that the information is up to the students. Based on the data from Figure 2, mostly of the respondents agree that parents, friends, educators, media and also promotion as their medium of receiving information about the job scope of engineering technology program. Therefore, resources may be a factor of effective whistle blower and act as a catalyst for young generation to enter the field of engineering technology. (Mean scores: 1: extremely not agreed, 2: not agreed, 3: moderate, 4: agreed and 5: extremely agreed). 


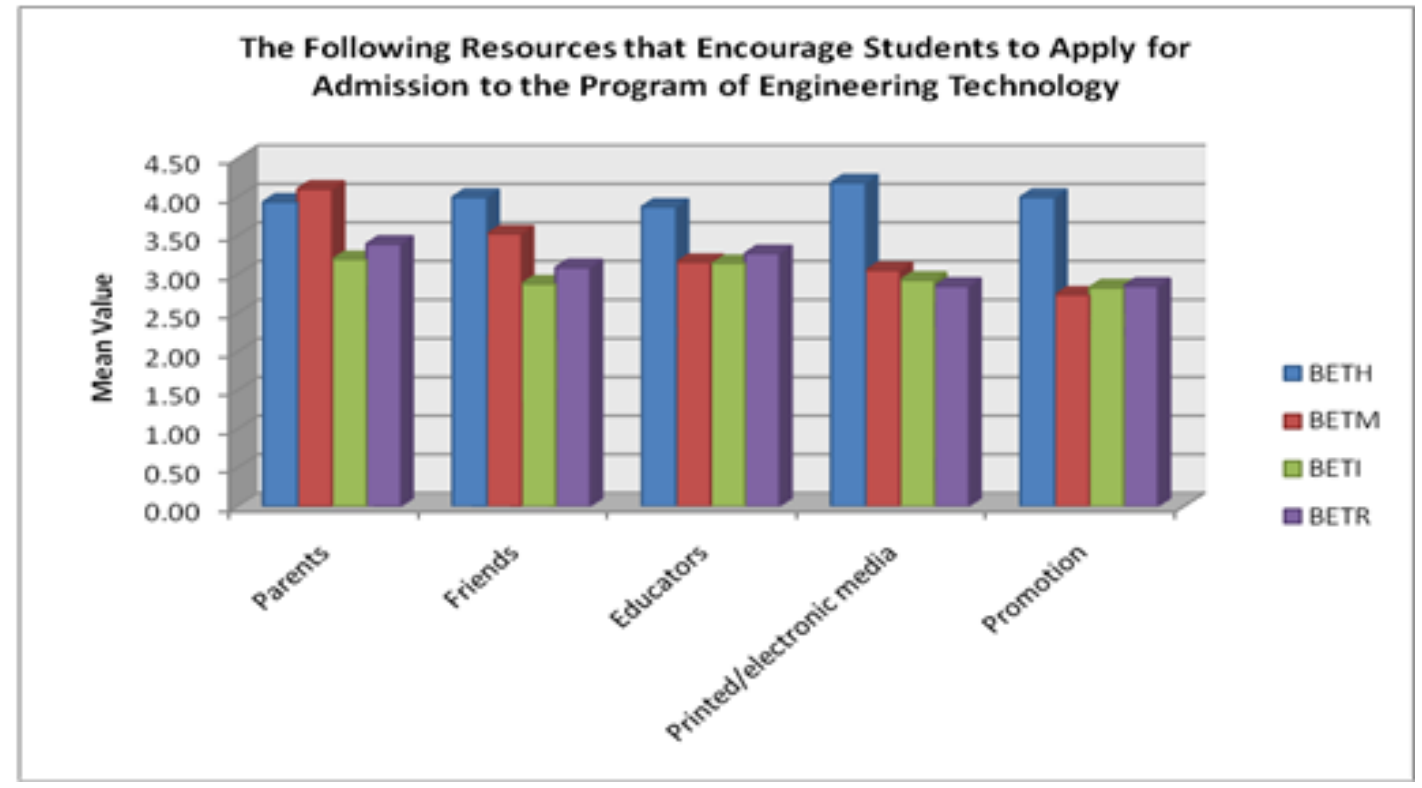

Figure 2 Response students about resources that encourage students to apply for admission to the program of Engineering Technology

\section{CONCLUSIONS}

In conclusion, the findings of market research survey show that there is an urgent need for improving Engineering Technology program in Malaysia in terms of understanding and job scope between Engineering and Engineering Technology Program. Most respondents agreed that Engineering Technologist program are related mostly on computer or information technology (IT) in respective syllabus. Not only that, the effective resources for the respondents effectively knows about Engineering Technologies comes from parents, friends, educators, promotion and printed or electronic media. This shows that, the promotions of Engineering Technology have done a great impact to the society but not affectively done in terms of understanding and job scope as technologist compared to engineer situation in Malaysia.

\section{ACKNOWLEDGEMENT}

The authors wish to acknowledge the work and dedication of the Working Committee for Engineering Technology Program from UTeM that has conducted the survey and came out with the analysis which has become the turning stone that has make the student's perception and understanding about Electrical and Mechanical Engineering Technology program. An appreciation is dedicated to industries and respondents involved in this research survey. The authors also would like to acknowledge Faculty of Engineering Technology, Universiti Teknikal Malaysia Melaka for supporting this study.

\section{REFERENCES}

[1]Craig Downing, Anneliese Watt, Julia Williams, and Rick Stamper 2011. Work in Progress Creating a Collaborative Learning Environment for Engineers and Technologists, 41st ASEE/IEEE Frontiers in Education Conference, pp T3G-1 - T3G-3 
[2]Perusich, K., Davis, B., Laware, G., Taylor, K., Taylor4 2007. Assessing Teamwork for Accreditation:Understanding What Needs to be Known and Its Integration into Engineering and Technology Curricula, 37th ASEE/IEEE Frontiers in Education Conference, pp T3E-1 - T3E-5

[3]Beute, N., Matlala, M.E. 2007. Ways Of Increasing The Pool Of Technologists And Engineers, And The Role Of The Teacher In-Service Training Program (Tisp) In The Field Of Technology And Engineering : A South African Approach, Meeting the Growing Demand for Engineers and Their Educators 2010-2020 International Summit, 2007 IEEE, pp 1-9

[4]Desai, A., Thomassian, J.-C. 2010. Imparting Business and Management Skills to Engineering Technologists through the Development of A Cross Disciplinary Program, Transforming Engineering Education: Creating Interdisciplinary Skills for Complex Global Environments, 2010 IEEE, pp 1-19 [5]Board of Engineers Malaysia (BEM), Institution of Engineers Malaysia (IEM), Federation of Engineering Institution of Islamic Countries (FEIIC). The Engineering, "Technology Path" Blueprint for a Highly Competent Engineering, Technical Workforce. February 2003.

[6]Yahaya, M. S., Noordin, A., Ahmad, S., \& Sapiee, M. M. (2012). Engineering technology program in Malaysia: A market survey. Procedia-Social and Behavioral Sciences, 56, 448-453.

[7]Goris, Tatiana V., Dyrenfurth, Michael J. 2011. Work in Progress - Analysis of Misconceptions of Engineering Technology Students about Electrical Technology Concepts. A Mixed Methods Study. 41st ASEE/IEEE Frontiers in Education Conference, pp T4J-1 - T4J-3 Ninth Malaysian Plan 20062010, The economic Planning Unit, Prime Ministers's Department,Putrajaya Malaysia, 2006.

[8]The Third Outline Perspective Plan 2001-2010 (OPP3), Economic Planning Unit (EPU), Prime Minister's Department, Putrajaya, Malaysia 2001. www.epu.gov.my. Retrieved Mei 2015. 